\title{
ASPEK-ASPEK FILOSOFI KEPEMIMPINAN DALAM AL-QURAN DAN AS-SUNNAH
}

\section{Hafniati}

Fakultas Agama Islam (FAI) Universitas Ibnu Chaldun (UIC) Jakarta Jl. Pemuda I Kav. 97 Rawamangun Jakarta Timur bafzul74@gmail.com

\section{Abstract}

Leadership is the ability of a person to influence and motivate others to do something according to common goals. Leaders must be based on the iman, ta'abbudi, charity sholeh and akhlaqul karimah in carrying out his leadership to achieve prosperity and salvation of the world and the hereafter. In the Qur'an and as-Sunnah are known several words of designation for leadership include: Khalifah, Amiir (ulul amr), and Imamah, region, and ri'ayah. A leader must have at least four aspects as Rasulullah $S A W$ exemplifies, namely: Shiddiq, Amanah, Tabligh and Fathanah. Shiddiq means honest in word and deed, trust means trustworthy in keeping responsibility, Tabligh means convey all kindness to its people and fathanah means smart in managing society. The purpose of leadership in Islam is to uphold Islam (Iqamatuddin) and world based on Shari' a Islam

\section{Abstrak:}

Kepemimpinan adalah kemampuan seseorang mempengarubi dan memotivasi orang lain untuk melakukan sesuatu sesuai tujuan bersama. Pemimpin harus harus didasari imani, ta'abbudi, amal sholeh dan akhlaqul karimah dalam menjalankan kepemimpinannya untuk mencapai kesejahteraan dan keselamatan ummat dunia dan akhirat. Dalam Al-Quran dan as-Sunnah dikenal beberapa kata sebutan untuk kepemimpinan antara lain: Khalifah, 
Amiir (ulul amr), dan Imamah, wilayah, dan ri'ayah. Seorang pemimpin minimal barus memiliki empat aspek sebagaimana Rasulullab SAW mencontohkan, yaitu: Shiddiq, Amanah, Tabligh dan Fathanah. Shiddiq berarti jujur dalam perkataan dan perbuatan, amanah berarti dapat dipercaya dalam menjaga tanggung jawab, Tabligh berarti menyampaikan segala macam kebaikan kepada rakyatnya dan fathanah berarti cerdas dalam mengelola masyarakat.Tujuan kepemimpinan dalam Islam adalab untuk menegakkan agama Islam (Iqamatuddin) dan dunia berdasarkan syariat Islam

Keyword: Filosofi, Leadership, al-Quran, as-Sunnah

\section{A. Pendahuluan}

Secara universal, manusia adalah makhluk Allah yang memiliki potensi yang paling bagus, mulia, pandai, dan cerdas. Mereka mendapatkan kepercayaan untuk menjalankan dan mengembankan amanat-Nya serta memperoleh kasih sayang-Nya yang sempurna. ${ }^{1}$

Sebagai wujud kesempurnaannya, manusia diciptakan oleh Allah setidaknya memiliki dua tugas dan tanggung jawab besar. Pertama, sebagai seorang hamba ('abdullab) yang berkewajiban untuk memperbanyak ibadah kepada-Nya sebagai bentuk tanggung jawab 'ubudiyyah terhadap Tuhan yang telah menciptakannya. Kedua, sebagai khalifatullah yang memiliki jabatan ilahiyah sebagai pengganti Allah dalam mengurus seluruh alam. Dengan kata lain, manusia sebagai khalifah berkewajiban untuk menciptakan kedamaian, melakukan perbaikan, dan tidak membuat kerusakan, baik untuk dirinya maupun untuk makhluk yang lain.

Tugas dan tanggung jawab itu merupakan amanat ketuhanan yang sungguh besar dan berat. Oleh karena itu, semua yang ada di langit dan di bumi menolak amanat yang sebelumnya telah Allah tawarkan kepada mereka. Akan tetapi, manusia berani menerima amanat tersebut, padahal ia memiliki potensi untuk mengingkarinya.

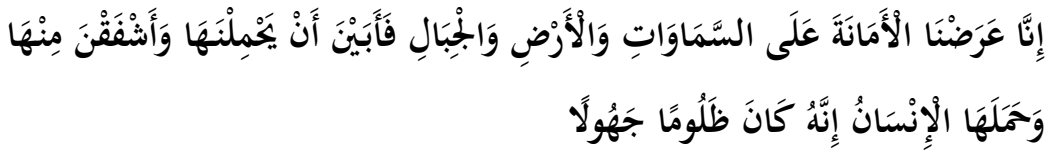

${ }^{1}$ Rachmat Ramadhana al-Banjari, Prophetic Leadership, (Yogyakarta: DIVA Press, 2008), h. 21 
Artinya:"Sesungguhnya Kami telah mengemukakan amanat kepada langit, bumi dan gunung-gunung, Maka semuanya enggan untuk memikul amanat itu dan mereka khawatir akan mengkbianatinya, dan dipikullah amanat itu oleh manusia. Sesunggubnya manusia itu amat zalim dan amat bodoh"(QS. Al-Ahzab:72)

Ibn 'Abbas sebagaimana dikutip oleh Ibn Kasir dalam tafsirnya "Tafsir al-Qur'an al-'Azim" menjelaskan bahwa yang dimaksud dengan amanat pada ayat di atas adalah ketaatan dan penghambaan atau ketekunan beribadah. ${ }^{2}$ Ada juga yang memaknai kata amanah sebagai al-taklif atau pembebanan, karena orang yang tidak sanggup memenuhinya berarti membuat utang atas dirinya. Adapun orang yang melaksanakannya akan memperoleh kemuliaan.

Dari sekian banyak penafsiran ulama tentang amanah, dapat ditarik sebuah "benang merah" yang dapat menghubungkan antara satu dengan yang lain, yaitu al-mas'uliyyah (tanggung jawab) atas anugerah Tuhan yang diberikan kepada manusia, baik berupa jabatan (hamba sekaligus khalifah) maupun nikmat yang sedemikian banyak. Dengan kata lain, manusia berkewajiban untuk menyampaikan "laporan pertanggungjawaban" di hadapan Allah atas limpahan karunia Ilahi yang diberikan kepadanya. Hal ini juga berarti bahwa pemimpin bukan hanya orang yang memiliki jabatan organisasi/instansi dan atau lembaga tertentu tetapi setiap manusia adalah pemimpin skala paling kecil.

Berbicara masalah pemimpin ideal menurut Islam erat kaitannya dengan figur Rasulullah SAW. Beliau adalah pemimpin agama dan juga pemimpin negara. Rasulullah merupakan suri tauladan bagi setiap orang, termasuk para pemimpin karena dalam diri beliau hanya ada kebaikan, kebaikan dan kebaikan. Hal ini sejalan dengan firman Allah dalam Al-Qur'an:

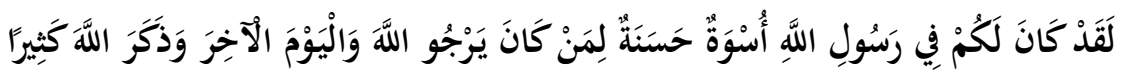

Artinya: "Sesunggubnya telah ada pada (diri) Rasulullah itu suri tauladan yang baik bagimu (yaitu) bagi orangyang mengharap (rabmat) Allah dan

2 'Imaad al-Din Abu al-Fida' Isma'il ibn Kasir al-Dimasyqi, Tafsir al-Qur'an al-Azim, Jil. XI, (Kairo: Muassasah Qurt\}ubah, 2000), h. 250. 
(kedatangan) hari kiamat dan Dia banyak menyebut Allah". (QS Al-Ahzab:21).

\section{B. Pengertian Kepemimpinan Dalam Islam}

Kepemimpinan (leadership) adalah proses mempengaruhi yang dilakukan oleh seseorang terhadap orang lain untuk dapat bekerja sama dalam mencapai tujuan atau sasaran bersama yang telah ditetapkan.(Maryanto dkk,2008:73).

Berdasarkan pengertian kepemimpinan di atas, pemimpin dapat didefinisikan sebagai individu yang memiliki pengaruh terhadap individu lain dalam sebuah system untuk mencapai tujuan bersama

Dalam Islam terdapat beberapa istilah yang digunakan untuk membahasakan istilah pemimpin, diantaranya sebagai berkut :

\section{a. Khalifah}

Dilihat dari segi bahasa, khalifah tiga macam makna yaitu mengganti kedudukan, belakangan dan perubahan. Dalam al-Qur'an ditemukan dua bentuk kata kerja dengan makna yang berbeda. Bentuk kata kerja yang pertama ialah khalafa-yakblifu dipergunakan untuk arti "mengganti", dan bentuk kata kerja yang kedua ialah istakblafa-yastakblifu dipergunakan untuk arti "menjadikan".

Pengertian mengganti di sini dapat merujuk kepada pergantian generasi ataupun pergantian kedudukan kepemimpinan. Tetapi ada satu hal yang perlu dicermati bahwa konsep yang ada pada kata kerja khalafa disamping bermakna pergantian generasi dan pergantian kedudukan kepemimpinan, juga berkonotasi fungsional artinya seseorang yang diangkat sebagai pemimpin dan penguasa di muka bumi mengemban fungsi dan tugas-tugas tertentu.

Dalam Al-Qur'an kata khalifah diulang beberapa kali dalam arti yang sama yaitu pemimpin, diantaranya yang sering digunakan adalah sebagaimana yang disebutkan dalam surat Al-Baqoroh ayat 30 .

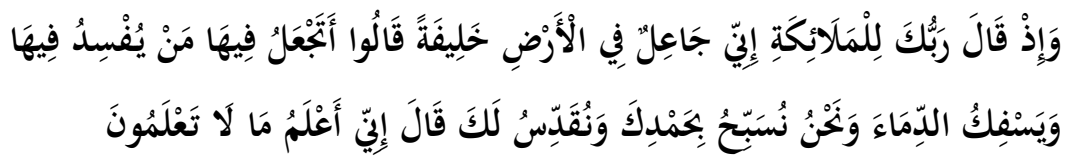

Artinya :"Ingatlah ketika Tubanmu berfirman kepada Para Malaikat: "Sesungguhnya aku hendak menjadikan seorang khalifah di muka bumi." mereka berkata: "Mengapa Engkau hendak menjadikan (khalifah) di bumi itu orang yang akan membuat kerusakan padanya 
dan menumpabkan darah, Padabal Kami Senantiasa bertasbih dengan memuji Engkau dan mensucikan Engkau?" Tuban berfirman: "Sesunggubnya aku mengetahui apa yang tidak kamu ketabui."( AlBaqoroh ayat 30).

b. Amiir (Ulul Amr)

Kata al-Amr itu sendiri merupakan bentuk mashdar dari kata kerja amara-ya 'muru artinya menyuruh atau memerintahkan atau menuntut seseorang untuk mengerjakan sesuatu. Dengan demikian Ulu al-Amr dapat kita artikan sebagai pemilik kekuasaan dan pemilik hak untuk memerintahkan sesuatu. Seseorang yang memiliki kekuasaan untuk memerintahkan sesuatu berarti yang bersangkutan memiliki kekuasaan untuk mengatur dan mengendalikan keadaan.

Al-Qur'an juga menegaskan pengertian yang sama dalam hal ini, sebagaimana difirmankan dalam surat An-Nisa:59

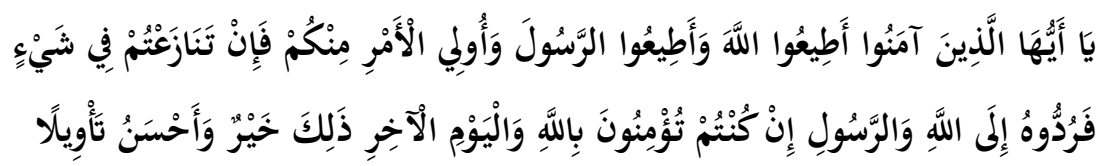

Artinya :"Hai orang-orang yang beriman, taatilah Allah dan taatilab Rasul (Nya), dan ulil amri di antara kamu. kemudian jika kamu berlainan Pendapat tentang sesuatu, Maka kembalikanlah ia kepada Allah (Al Quran) dan Rasul (sunnabnya), jika kamu benar-benar beriman kepada Allah dan hari kemudian. yang demikian itu lebih utama (bagimu) dan lebih baik akibatnya."(Q.S. An-Nisa:59).

Berdasarkan ayat diatas dapat dipahami bahwa pemimpin adalah sesorang yang memiliki hak atau wewenang untuk memerintah atas dasar ketaatan kepada Allah dan Rasul-Nya. Sehingga ketaatan kepada seorang pemimpin harus ditarik garis lurus selama masih sejalan dengan perintah Allah dan Rasul-Nya.

c. Imam (imaamah)

Menurut Prof. Dr. H. Mahmud Yunus, kata Imam berarti pemimpin, ikutan, atau panutan, sedangkan imaamah berarti keimaman atau kepemimpinan. ${ }^{3}$

Kata imam dalam kepemimpinan Islam lebih spesifik terhadap aspek keteladanan, artinya seorang Imam adalah seorang figur yang

3 Mahmud Yunus, Kamus Arab-Indonesia. (Jakarta: Mahmud Yunus wadzuriyyah, 1998), h. 48 
mampu menjadi panutan dan memberi keteladanan (uswatun hasanah) bagi rakyatnya. Hal ini sesuai dengan firman Allah dalam surat Al-Isro ayat 17.

\section{وَكَمْ أَهْلَكْنَا مِنَ الْقُرُونِ مِنْ بَعْدِ نُوح وَكَفَى برَبَّكَ بِذْنُوبْ عِبَادِهِ خَبِيرًا بَصِيرًا}

Arinya :"(Ingatlah) suatu hari (yang di hari itu) Kami panggil tiap umat dengan pemimpinnya; dan Barangsiapa yang diberikan kitab amalannya di tangan kanannya Maka mereka ini akan membaca kitabnya itu, dan mereka tidak dianiaya sedikitpun”. (Q.S. Al-Isro :71).

\section{d. Al-Wilayah}

Kalimat wali kadangkala artinya mutawali (orang yang mengatur) semua urusan dan memiliki otoritas untuk bertindak terhadap suatu perkara, orang yang mempunyai kekuasaan negara/wilayah, yang memotivassi rakyat, dan sebagainya. Terkadang kata wali artinya penolong atau kawan, dan diartikan juga pelindung dan penolong.

Ketika Al-Qur'an memerintahkan mencintai orang-orang yang beriman dan melarang mencintai di luar orang-orang mukmin dari orang-orang kafir dan ahli kitab, maka munvalah diartikan memberikan pertolongan dan kecintaan seperti firman Allah SWT:

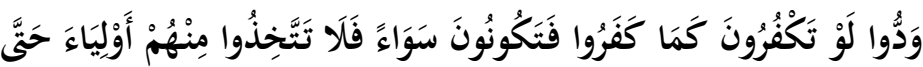

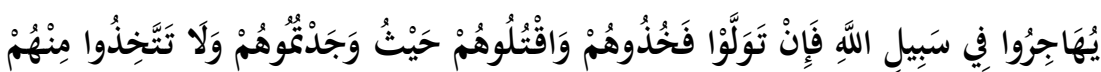

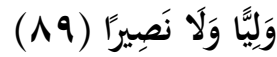

Artinya: "Mereka ingin supaya kamu menjadi kafir sebagaimana mereka telah menjadi kafir, lalu kamu menjadi sama (dengan mereka). Maka janganlab kamu jadikan di antara mereka penolong-penolong (mu), bingga mereka berbijrah pada jalan Allah. Maka jika mereka berpaling, tawan dan bunublab mereka di mana saja kamu menemuinya, dan janganlah kamu ambil seorangpun di antara mereka 
menjadi pelindung, dan jangan (pula) menjadi penolong" (An-Nisa 89)

e. Ar-Riayah

Ro'i mencakup kepemimpinan negara, masyarakat, rumah tangga, kepemimpinan moral, yang mencakup juga kepemimpinan laki-laki maupun wanita. Oleh karena itu, tak seorang pun di dunia ini lepas dari tanggung jawab kepemimpinan, minimal terhadap dirinya sendiri. Setiap orang mengemban amanah, dan setiap amanah pasti akan dimintai pertanggungjawabannya.

Ro'i berasal dari bahasa arab bersuku kata ro'a-yar'a-ro'yanriayatan. Kepemimpinan dalam terminologi ro'i menyiratkan pentingnya makna riayah yang artinya menggembala, memelihara, mengarahkan, dan memberdayakan orang-orang yang ada dipimpinnya (ra'iyab). Kata rakyat dalam bahasa Indonesia berasal dari kata ra'iyah.

Rasulullah bersabda:

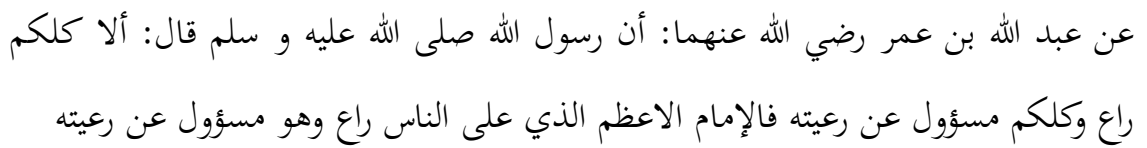

Artinya: "..... Abdullah bin Umar r.a. berkata babwa Rasulullab saw telah bersabda, "Ketabuilah: Kalian semua adalab pemimpin (pemelihara) dan bertanggung jawab terhadap rakyatnya. Pemimpin akan dimintai pertanggungjawabannya tentang rakyat yang dipimmpinnya.

\section{Dasar-dasar kepemimpinan menurut al-Quran dan as- Sunnah}

a. Berdasarkan al-Quran

4 Abu 'Abdillah Muhammad ibn Isma'il al-Bukhari, al-Jami' al-Sabih alMusnad min Hadis Rasulillah Sallallahu 'alaibi wa Sallam wa Sunanibi wa Ayyamibi, Jil. III (Kairo: al-Matba'ah al-Salafiyyah, 1403 H), h. 328. 


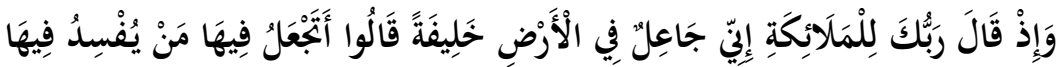

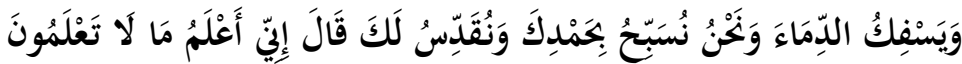

Artinya: "Ingatlah ketika Tuhanmu berfirman kepada Para Malaikat: "Sesunggubnya aku hendak menjadikan seorang khalifah di muka bumi." mereka berkata: "Mengapa Engkau hendak menjadikan (khalifah) di bumi itu orang yang akan membuat kerusakan padanya dan menumpabkan darah, padahal kami senantiasa bertasbih dengan memuji Engkau dan mensucikan Engkau?" Tuban berfirman: "Sesunggubnya aku mengetahui apa yang tidak. kamu ketabui." (Q.S. Al-Baqoroh :30)

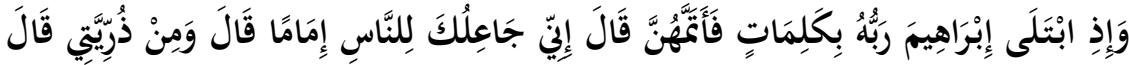

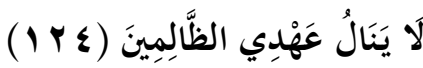

Artinya :"Dan ingatlah ketika Ibrabim diuji Tubannya dengan beberapa kalimat (perintah dan larangan), lalu Ibrahim menunaikannya. Allah berfirman: "Sesunggubnya aku akan menjadikanmu imam bagi seluruh manusia". Ibrahim berkata: "(Dan saya mohon juga) dari keturunanku". Allah berfirman: "Janji-Ku (ini) tidak mengenai orang yang zalim" (Q.S. Al-Baqoroh :124)

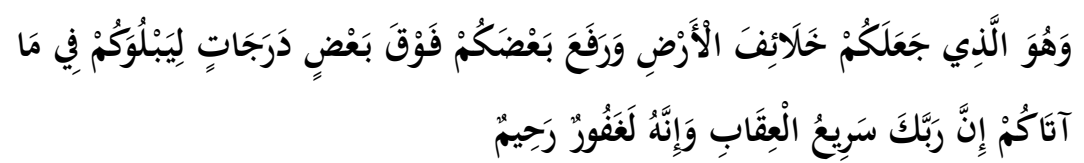

Artinya :"Dan Dia lah yang menjadikan kamu penguasa-penguasa di bumi dan Dia meninggikan sebabagian kamu atas sebahagian (yang lain) beberapa derajat, untuk mengujimu tentang apa yang diberikan-Nya kepadamu. Sesunggubnya Tubanmu Amat cepat siksaan-Nya dan Sesungguhnya Dia Maha Pengampun lagi Maha Penyayang”( Q.S. Al-An'am : 165).

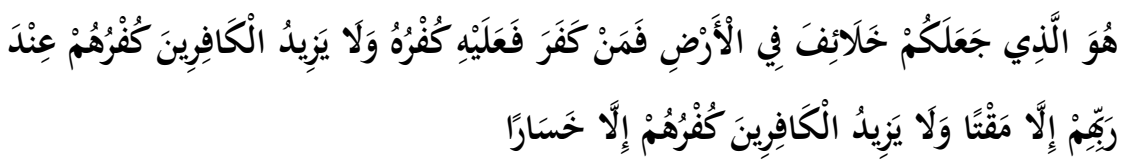

Artinya: "Dia-lah yang menjadikan kamu khalifah-khalifah di muka bumi. Barangsiapa yang kafir, Maka (akibat) kekafirannya menimpa 
dirinya sendiri. dan kekafiran orang-orang yang kafir itu tidak. lain banyalah akan menambah kemurkaan pada sisi Tubannya dan kekafiran orang-orang yang kafir itu tidak lain hanyalah akan menambah kerugian mereka belaka."(Q. S. Al Fathir: 39)

\section{b. Berdasarkan as-Sunnah}

عن عبد الله بن عمر رضي الله عنهما: أن رسول الله صلى الله عليه و سلم قال: ألا كلكم راع وكلكم مسؤول عن رعيته فالإمام الاعظم الذي على الناس راع وهو مسؤول عن رعيته والرجل راع على أهل بيته وهو مسؤول عن رعيته والمرأة راعية على أهل بيت زوجها وولده وهي مسؤولة عنهم وعبد الرجل راع على مال سيده وهو مسؤول عنه ألا فكلكم راع وكلكم مسؤول عن رعيته

Artinya:"Dari Abdullab bin Umar r.a. berkata babwa Rasulullah saw telab bersabda, "Ketabuilah: Kalian semua adalab pemimpin (pemelihara) dan bertanggung jawab terbadap rakyatnya. Pemimpin akan dimintai pertanggungjawabannya tentang rakyat yang dipimmpinnya. Suami adalah pemimpin bagi keluarganya dan akan dimintai pertanggungjawabannya tentang keluarga yang dipimpinnya. Isteri adalah pemelihara rumah suami dan anak-anaknya. Budak adalah pemelihara harta tuanny a dan ia bertanggung jawab mengenai hal itu. Maka camkanlah bahwa kalian semua adalah pemimpin dan akan dituntut (diminta pertanggungjawaban) tentang bal yang dipimpinnya” (H.R. Bukhari)

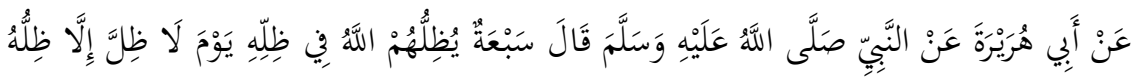

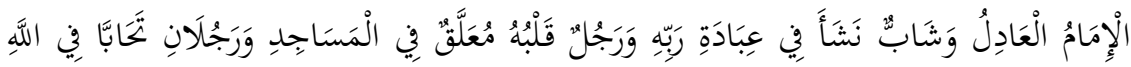

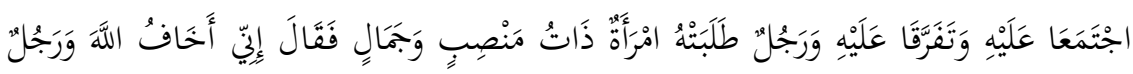

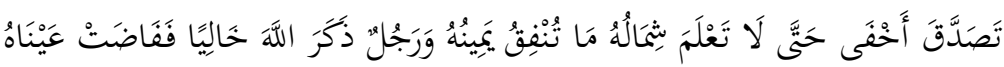

Artinya: "Dari Abu Hurairah r.a. dari Nabi saw, beliau bersabda: "Ada tujuh kelompok yang akan mendapat naungan Allah pada hari yang tiada naungan kecuali naungan-Nya yaitu: Pemimpin yang adil, remaja yang senantiasa beribadah kepada Allah ta'alaa, seseorang 
yang senantiasa batinya dipertautkan dengan masjid, dua orang yang saling cinta mencintai karena Allah dimana keduanya berkumpul dan berpisah karena-Nya, seorang laki-laki yang ketika dirayu oleh wanita bangsawan lagi rupawan, lalu menjawab: "sesunggubnya saya takut kepada Allab", seseorang yang mengeluarkan shadakah kemudian ia merahasiakannya sampai-sampai tangan kiri tidak mengetabui apa yang diberikan oleh tangan kanannya, dan seseorang yang berdzikir kepada Allah di tempat yang sunyi kemudian kedua matany meneteskan air mata" H.R. Bukhari-Muslim).

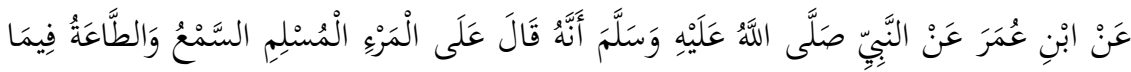

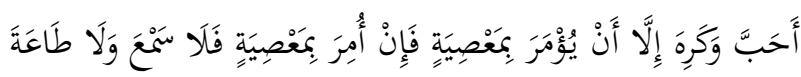

Artinya :"Dari Ibn Umar ra., dari Nabi Saw., sesunggubnya bliau bersabda: "Seorang Muslim wajib mendengar dan taat terhadap perintah yang disukai maupun tidak disukainya. Kecuali bila diperintabkan mengerjakan kemaksiatan, maka ia tidak wajib mendengar dan taat” H.R. Bukhari Muslim).

$$
\begin{aligned}
& \text { حديث عبدالرّمن بن سمرة، قال: قال النّى صلّى الله عليه وسلّم: يا عبدالرّممن إبن سمرة! } \\
& \text { لاتسأل الإمارة، إن أوتيتها عن مسئلة وكلت أليها، وإن أوتيتها من غير مسئلة أعنت عليها. } \\
& \text { أخرجه البخارى في: بم كتاب الأيمان والنذور: الباب قول الله تعالى - لا يؤاخذكم الله } \\
& \text { باللغو في أيمانكم }
\end{aligned}
$$

Artinya: "Hadits diriwayatkean oleh Abdurrahman bin Samurah, ia berkata: Telah bersabda Nabi SAW: "Wahai Abdurrabman janganlah engkau mengharapkan suatu jabatan. Sesunggubnya jika jabatan itu diberi karena ambisimu maka kamu akan menanggung selurub bebannya. Namun bila engkau ditugaskan tanpa ambisimu, maka kamu akan ditolong oleb Allah SWT untuk mengatasinya" (H.R. Bukhari)

\section{Filosofis kepemimpinan menurut al-Quran dan as-Sunnah}

Islam memberi gambaran tentang sosok pemimpin yang benar-benar layak memimpin umat menuju kemaslahatan dan 
keselamatan dunia dan akhirat, baik dari Al-Qur'an, Hadist, maupun keteladanan Rasul SAW dan para sahabat sebagai sosok pemimpin ideal bagi umat Islam.

Pemimpin ideal menurut Islam erat kaitannya dengan figur Rasulullah SAW. Beliau adalah pemimpin agama dan juga pemimpin negara. Rasulullah SAW merupakan suri tauladan bagi setiap orang, termasuk para pemimpin karena dalam diri beliau yang ada hanya kebaikan. Hal ini sejalan dengan firman Allah dalam Al-Qur'an:

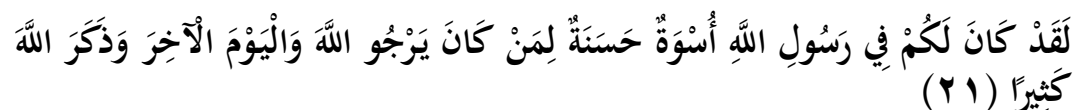

Artinya: "Sesunggubnya telab ada pada (diri) Rasulullah itu suri teladan yang baik bagimu (yaitu) bagi orang yang mengharap (rahmat) Allah dan (kedatangan) hari kiamat dan Dia banyak menyebut Allah." (QS Al-Ahzab:21)

Pada dasarnya, kepemimpinan itu adalah amanah yang akan dipertanggungjawabkan di sisi Allah SWT. Oleh karena itu, Islam telah menggariskan beberapa kaedah yang berhubungan dengan kepemimpinan. Kaedah-kaedah tersebut dapat diringkas sebagai berikut:

a. Kepemimpinan Bersifat Tunggal

Dalam khazanan politik Islam, kepemimpinan negara itu bersifat tunggal. Tidak ada pemisahan, ataupun pembagian kekuasaan di dalam Islam. Kekuasaan berada di tangan seorang Khalifah secara mutlak. Seluruh kaum Muslim harus menyerahkan loyalitasnya kepada seorang pemimpin yang absah. Mereka tidak diperbolehkan memberikan loyalitas kepada orang lain, selama Khalifah yang absah masih berkuasa dan memerintah kaum Muslim dengan hukum Allah SWT.

Dalam hal ini, Rasulullah Saw bersabda:

Artinya: "Siapa saja yang telah membai'at seorang Imam (Khalifah), lalu ia memberikan uluran tangan dan buah hatinya, hendaknya ia mentaatinya jika ia mampu. Apabila ada orang lain bendak merebutnya (kekuasaan itu) maka penggallah leher orang itu." [HR. Muslim].

b. Kepemimpinan Islam Itu Bersifat Universal 
Kepemimpinan Islam itu bersifat univeral, bukan bersifat lokal maupun regional. Artinya, kepemimpinan di dalam Islam diperuntukkan untuk Muslim maupun non-Muslim. Sedangkan dari sisi konsep kewilayahan, Islam tidak mengenal batas wilayah negara yang bersifat tetap sebagaimana konsep kewilayahan negara bangsa. Allah SW'T berfirman dalam surat as Saba':28

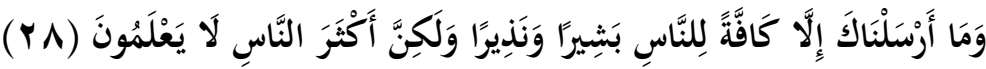

Artinya: "Dan Kami tidak mengutus kamu, melainkan kepada umat manusia selurubnya sebagai pembawa berita gembira dan sebagai pemberi peringatan, tetapi kebanyakan manusia tiada mengetabui."

c. Kepemimpinan itu adalah amanah

Pada dasarnya, kepemimpinan itu adalah amanah yang membutuhkan karakter dan sifat-sifat tertentu. Dengan karakter dan sifat tersebut seseorang akan dinilai layak untuk memegang amanah kepemimpinan. Atas dasar itu, tidak semua orang mampu memikul amanah kepemimpinan, kecuali bagi mereka yang memiliki sifat-sifat kepemimpinan.

Allah mengisyaratkan dengan tegas untuk mengangkat "pelayan rakyat" yang kuat dan dapat dipercaya dalam surat Al-Qashash ayat 26.

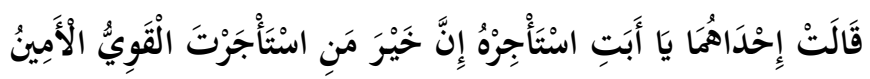

Artinya :"Salah seorang dari kedua wanita itu berkata: "Ya bapakku ambillah ia sebagai orang yang bekerja (pada kita), karena Sesunggubnya orang yang paling baik yang kamu ambil untuk bekerja (pada kita) ialah orang yang kuat lagi dapat dipercaya".

Amanah merupakan kualitas yang harus dimiliki seorang pemimpin. Dengan memiliki sifat amanah, pemimpin akan senantiasa menjaga kepercayaan masyarakat yang telah dibebankan sebagai amanah mulia di atas pundaknya. Kepercayaan masyarakat berupa penyerahan segala macam urusan kepada pemimpin agar dikelola dengan baik dan untuk kemaslahatan bersama. 


\section{E. Kriteria Kepemimpinan dalam Islam}

Islam adalah agama yang kaafah (sempurna), yang diturunkan Allah melalui perantara Rasul-Nya yang amanah dengan membawa syariat yang mengatur seluruh aspek kehidupan manusia, baik yang berhubungan dengan Allah Swt (Hablum minallab) maupun hubungan dengan manusia (Hablumminannas), termasuk di antaranya yang paling prinsip adalah masalah kepemimpinan.

Masalah kepemimpinan di kalangan umat Islam mulai ramai dibicarakan sejak sepeninggal Rasulullah saw. Diugkapkan oleh Abdurrahman Asy Syarqowi (2010:92) bahwa sepeninggal Rosululah terjadi kekosongan pemimpinan. Terjadi beberapa gesekan bagi mereka yang masih hidup seperti halnya udara yang masuk dari ruang kosong yang saling bertabrakan. hingga akhirnya disepakati Abu Bakar sebagai kholifah pertama.

Dalam Islam gambaran tentang sosok pemimpin yang benarbenar layak memimpin umat menuju kemaslahatan, baik dari AlQur'an, Hadist, maupun keteladanan Rosul dan para sahabat. sebagai sosok pemimpin ideal bagi umat Islam, Rosulullah saw. memiliki beberapa kriteria yang dapat ditentukan dalam hal memilih seorang pemimpin antara lain:

a. Shidiq (Jujur)

Kejujuran adalah lawan dari dusta dan ia memiliki arti kecocokan sesuatu sebagaimana dengan fakta. Nabi Muhammad saw. sebagai utusan terpercaya Allah jelas tidak dapat lagi diragukan kejujurannya, kerena apa yang beliau sampaikan adalah petunjuk (wahyu) Allah yang bertitik pada kebenaran yaitu ridlo Allah. Sebagaimana difirmankan dalam QS. An-Najm:3-4.

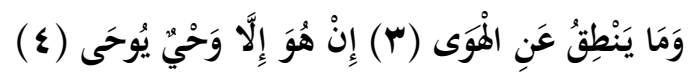

Artinya: "Dan tiadalah yang diucapkannya itu (Al-Quran) menurut kemanan hawa nafsunya. ucapannya itu tiada lain hanyalab wabyu yang diwabyukan (kepadanya)

b. Amanah/Terpercaya

Allah mengisyaratkan dengan tegas untuk mengangkat "pelayan rakyat" yang kuat \& dapat dipercaya dalam surat Al-Qoshos ayat 26.

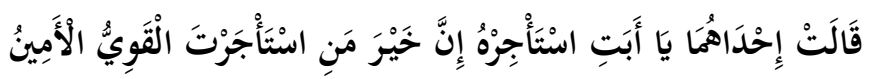


Artinya: "Salah seorang dari kedua wanita itu berkata: "Ya bapakku ambillah ia sebagai orang yang bekerja (pada kita), karena Sesunggubnya orang yang paling baik yang kamu ambil untuk. bekerja (pada kita) ialah orang yang kuat lagi dapat dipercaya".

Amanah merupakan kualitas yang harus dimiliki seorang pemimpin. Dengan memiliki sifat amanah, pemimpin akan senantiasa menjaga kepercayaan masyarakat yang telah dibebankan sebagai amanah mulia di atas pundaknya. Kepercayaan maskarakat berupa penyerahan segala macam urusan kepada pemimpin agar dikelola dengan baik dan untuk kemaslahatan bersama.

c. Tabligh (Komunikatif)

Kemampuan berkomunikasi merupakan potensi dan kualitas prinsip yang harus dimiliki oleh seorang pemimpin. Karena dalam kinerjanya mengemban amanat memaslahatkan umat, seorang pemimpin akan berhadapan dengan kecenderungan masayarakat yang berbeda-beda. Oleh karena itu komunikasi yang sehat merupakan kunci terjalinnya hubungan yang baik antara pemimpin dan rakyat.

Allah berfirman yang rtinya :"Hai orang-orang yang beriman, penubilah seruan Allah dan seruan Rasul apabila Rasul menyeru kamu kepada suatu yang memberi kehidupan kepada kamu, ketabuilah babwa Sesunggubnya Allah membatasi antara manusia dan hatinya dan Sesungguhnya kepadaNyalah kamu akan dikumpulkan."

Salah satu ciri kekuatan komunikasi seorang pemimpin adalah keberaniannya menyatakan kebenaran meskipun konsekuensinya berat. Dalam istilah Arab dikenal ungkapan, "kul al-haq walau kaana murran", katakanlah atau sampaikanlah kebenaran meskipun pahit rasanya.

d. Fathanah (cerdas)

Seorang pemimpin sebagai visioner haruslah orang yang berilmu, berwawasan luas, cerdas, kreatif, dan memiliki pandangan jauh ke depan. Karena untuk mewujudkan kemaslahatan dan kemakmuran masyarakat dibutuhkan pemikiran besar dan inovatif serta tindakan nyata. Kecerdasa (inteleligen) dalam hal ini mencakup segala aspek kecerdasan, baik kecerdasan emosional (EQ), spiritual (SQ) maupun intelektual (IQ).

Cerdas sendiri dapat diartikan sebagai "kemampuan individu untuk memahami, berinovasi, memberikan bimbingan yang terarah untuk perilaku, dan kemampuan mawas diri. Ia merupakan 
kemampuan individu untuk memahami masalah, mencari solusinya, mengukur solusi atau mengkritiknya, atau memodifikasinya".(AlHajjaj,2009:20).

Kecerdasan seorang pemimpin akan sangat mempengaruhi eksistensi kepemimpinannya baik di mata manusia maupun dimata sang pencipta. Hal ini sebagaimana janji Allah yang tertuang dalam surat Al-Mujadalah ayat 11.

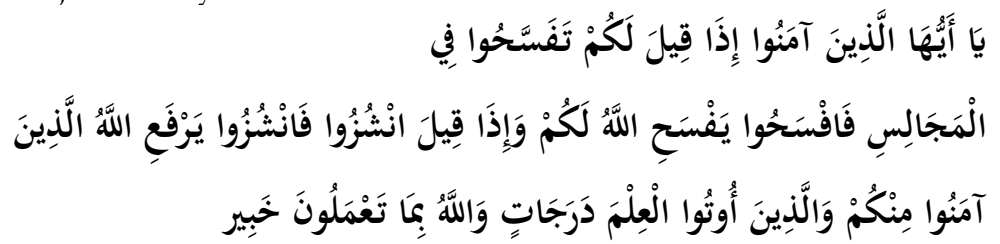

Artinya :"...Niscaya Allah akan meninggikan orang-orang yang beriman di antaramu dan orang-orang yang diberi ilmu pengetahuan beberapa derajat. dan Allah Maha mengetahui apa yang kamu kerjakan".(Q.S. Al-Mujadalah:11).

Selain aspek-aspek diatas, masih banyak kiteria yang layaknya dimiliki oleh pemimpin ideal seperti :

\section{Demokratis}

Dalam hal ini pemimpin tidak sembarang memutuskan sebelum adanya musyawarah yang mufakat. Sebab dengan keterlibatan rakyat terhadap pemimpinnya dari sebuah kesepakatan bersama akan memberikan kepuasan, sehingga apapun yang akan terjadi baik buruknya bisa ditanggung bersama-sama.

Pola kepemimpinan yang demokratis dapat diteladani dari pribadi Abu Bakar As-Shidiq. Hal ini dapat dilirik dari kutipan Khutbahnya ketika terpilih sebagai kholifah pertama.

"Saudara-saudara, Aku telah diangkat menjadi pemimpin bukanlah karena aku yang terbaik diantara kalian semuanya, untuk itu jika aku berbuat baik bantulah aku, dan jikea aku berbuat salah luruskanlab aku. Sifat jujur itu adalah amanah, sedangkan kebohongan itu adalah pengkbianatan. 'Orang lemab' diantara kalian aku pandang kuat posisinya di sisiku dan aku akan melindungi hak-haknya. 'Orang kuat' diantara kalian aku pandang lemah posisinya di sisiku dan aku akan mengambil hak-bak mereka yang mereka peroleh dengan jalan yang jahat untuk aku kembalikan kepada yang berbak menerimanya. Janganlah diantara kalian meninggalkan jibad, sebab kaum yang meninggalkan jihad akan ditimpakan kehinaan oleh Allah Swt. Patublab kalian kepadaku selama aku mematubi Allab dan Rasul-Nya. Jika 
aku durbaka kepada Allah dan Rasul-Nya maka tidak ada kewajiban bagi kalian untuk mematubiku. Kini marilab kita menunaikan Sholat semoga Allah Swt melimpabkan Rahmat-Nya kepada kita semua". (AsySyarqowi,2010:98).

2. Keteladanan (qudwab)

Aspek keteladanan erat hubungannya dengan budi pekerti (akhlak), dan hal inilah yang diperankan tokoh pemimpin muslim ideal terdahulu. Rosulullah saw sebagai figur utama pemimpin muslim banyak memberi siraman tentang nilai-nilai pekerti kepada umatnya, seperti yang ditamankan kepada seorang pemimpin legendaris mislim yang mengenyam pelajaran kenabian sejak kecil dari beliau, Ali bin Abi Tholib.

Seperti wasiat nabi kepada Ali yang dikutip dari buku Abdurrahman Asy Sarqowi (2002:10) "Wabai Ali, maukah aku tunjukkan kepadamu akblak terbaik orang-orang terdabulu orang-orang (yang akan datang) kemudian?. Ali menjawab, ya, Rosulullah. Rosulullah saw. kembali bersabda engkau memberi orang yang kikir kepadamu, memaafkan orang yang mendzalimimu, dan menyambungkan tali silaturrabmi kepada orang yang telah memutuskannya".

Allah berfirman dalam surat Al-Qalam ayat 4 :

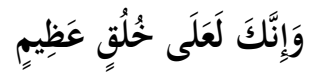

Artinya :Dan Sesunggubnya kamu benar-benar berbudi pekerti yang agung.(Q.S. Al-Qolam:4).

3. Kepeloporan

Seorang sebagai qudwah (panutan) bagi rakyatnya harus memempatkan dirinya pada garda terdepan (pioneer), yang berarti kinerjanya tidak hanya bermodal intelektual, retorika yang menjanjikan atau hanya konsep belaka, tapi juga harus dibuktikan dalam tindakan nyata. Dalam hal ini Allah SWT menegaskan dalam surat Az-Zumar ayat 20.

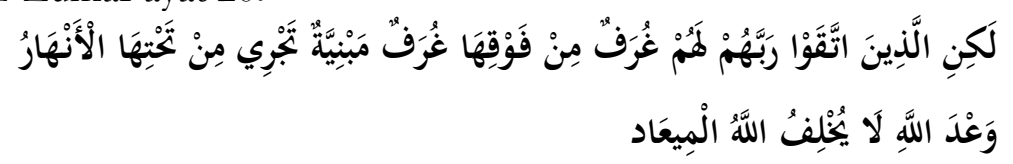

Artinya: "Dan aku diperintabkan supaya menjadi orang yang pertama-tama berserah diri".(Q.S. Az-Zumar:20).

Para tokoh pemimpin muslim ideal terdahulu selalu menunjukkan kepeloporannya dalam memimpin rakyatnya. Sebut 
saja K.H. Abdurrahman Wahid (gus dur) tokoh nasionalis yang gigih memperjuangkan pluralism di Indonesia. Gusdur berada di barisan garda depan untuk memperkuat pluralism di republic ini. Istimewanya, pluralism yang dikembangkan gus dur tidak hanya pada tataran pemikiran. Melainkan menjadi sebuah tindakan socialpolitik.(Misrawi,2002:X).

4. Menguasai pengetahuan Agama (religious).

Allah mengingatkan kaum muslimin bahwa orang yang paling takut kepada-Nya adalah ulama' (orang-orang yang menguasai pengetahuan Agama.

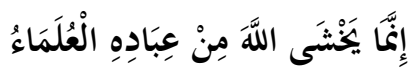

Artinya :"...Sesunggubnya yang takut kepada Allah di antara hamba-hamba-

Nya, banyalab ulama. (QS. Fathir: 28)

Dari ayat diatas jelas menunjukkan bahwa seorang pemimpin hendaklah menguasai pengetahuan tentang agama Allah, karena mereka hanya mengembalikan segala urusan kepada Allah dan RosulNya tidak semata-mata atas dasar keinginan dirinya sendiri.

Imam ghozali menjelaskan tentang sifat-sifat terpuji ulama' dalam kitabnya majmu'ah rosaail yang diterjemahkan oleh Irwan Kurniawan (2010:17) bahwa “ adab seorang ulama' antra lain : selayaknya terus mencari dan mengamalkan ilmu, memelihara ketenangan, meninggalkan sifat takabur dan tidak mengundangnya. Mengasihi pencari ilmu dan tidak bersegera kepada orang sombong. Menyelesaikan masalah orang awam dan tidak merasa gengsi untuk mengatakan, "saya tidak tahu." Memberikan perhatian serius atas pertanyaan penanya dan tidak berpura-pura. Memperhatikan dan menerima argument, walaupun itu berupa bantahan."

5. Menguasai managemen (manajerial)

Allah berfirman dalam surat As-Saff ayat 4:

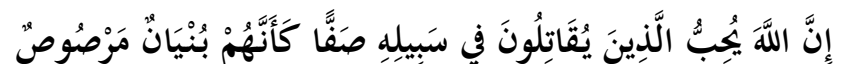

Artinya :Sesunggubnya Allab menyukai orang yang berperang dijalan-Nya dalam barisan yang teratur seakan-akan mereka seperti suatu bangunan yang tersusun kokoh.

Dari ayat diatas, dapat dipahami bahwa seorang pemimpin

harus memiliki kemampuan mengelola dan mengorganisasikan 
system secara teratur, agar terbangun system pemerintahan yang kokoh.

\section{F. Tujuan Kepemimpinan dalam Islam}

Kepemimpinan dalam Islam memiliki dua tujuan pokok yang harus direalisasikan, yaitu :

a. Menegakkan Agama Islam (Iqamatuddin)

Imam Al-Kamal Bin Hammad Al-Hanafi berkata, "Tujuan pertama dalam penegakkan imamah (kepemimpinan) adalah untuk menegakkan agama. Maksudnya adalah menegakkan syi'ar-syi'ar agama sebagaimana yang diperintahkan oleh Allah, yaitu dengan memurnikan segala ketaatan kepada Allah, menghidupkan sunnah-sunnah, dan menghilangkan bid'ah agar seluruh manusia bisa sepenuhnya menaati Allah Ta'ala." "5yaikh Ad-Dumaiji menjelaskan bahwa penegakkan Islam bisa dicapai dengan dua cara yang dilaksanakan secara serentak, yaitu:

b. Menjaga Kemurniaan Agama (Hifzhuddin),

Yaitu menjaga kemurnian pemahaman Islam dari segala keyakinan yang menyimpang atau pemikiran-pemikiran sesat yang dapat menghilangkan keotentikan ajaran Islam. Seorang pemimpin memiliki kewajiban untuk menjaga kemurnian akidah rakyatnya. Menjaga pemahaman mereka agar sesuai dengan apa yang telah disampaikan oleh Rasulullah Shallallahu 'alaihi wa sallam.

Dalam tataran pelaksanaannya, ada beberapa hal yang harus dilaksanakan oleh pemimpin agar kemurnian ajaran Islam tetap terjaga:.

1) Menyebarkan dakwah di tengah kaum Muslimin dan senantiasa menyeru umat-umat non Muslim kepada ajaran Islam.

\footnotetext{
${ }^{5}$ Al-Musamarah Syarh Al-Musayarah, h. 153
} 
2) Mendakwahi penguasa kafir dan bangsa-bangsa non Muslim melalui jalan jihad, yaitu dengan menawarkan tiga pilihan: masuk Islam, bayar jizyah, atau perang.

3) Menolak segala macam bentuk bid'ah, syubhat dan pemikiran-pemikiran batil yang menyelisihi sunnah.

4) Melaksanakan ajaran Islam dalam semua aspek kehidupan. (Tanfidruddin)

Syariat Islam diterapkan oleh imam dengan cara menegakkan hukum-hukum Allah serta membimbing masyarakat untuk menaati perintah-perintah syar'i dan menjauhi larangan-larangan-Nya. Ibnu Taimiyah berkata, "Penegakkan hudud adalah kewajiban pemimpin, yaitu dengan menetapkan hukuman bagi siapa saja yang meninggalkan kewajiban atau melakukan perbuatan haram." 'Dalam hal ini, di antara hal yang menjadi kewajiban pemimpin adalah:

1) Mengelola zakat, fa'i, ghanimah, jisyah, kharaj, wakaf dan sedekah.

2) Mengatur dan mengirim pasukan-pasukan jihad fi sabilillah.

3) Menegakkan hukum-hukum budud dan jinayat (pidana) atas perilaku kriminal.

4) Mendirikan pengadilan syariat dan mengangkat para qadhi (hakim syariat) yang mengadili perkara-perkara syariat.

5) Mendirikan lembaga hisbah yang bertugas melaksanakan amar ma'ruf nahi mungkar.

c. Mengatur Dunia Berdasarkan Syariat Islam

Para ulama sepakat bahwa seorang pemimpin wajib mengatur seluruh aspek kehidupan manusia berdasarkan syariat Allah, baik dalam bidang politik, ekonomi, sosial, budaya, maupun militer. Semuanya harus sesuai dengan petunjuk Al-Qur'an dan As-Sunnah. Karena seluruh aturan manusia telah Allah tetapkan di dalamnya.

Syariat Islam merupakan hukum yang bersifat syumul, berlaku setiap kondisi dan tidak pernah lekang dengan bergantinya zaman. Semuanya ditetapkan oleh Dzat yang Maha Mengetahui segala sesuatu. Tidak ada hukum yang lebih baik dan sempurna daripada

${ }^{6}$ Ibnu Taimiyah, Al-Hisbah, h. 55 
hukum Allah. Oleh karena itu Allah pun memerintahkan kepada hamba-Nya untuk senantiasa mentaati hukum Nya Firman-Nya:

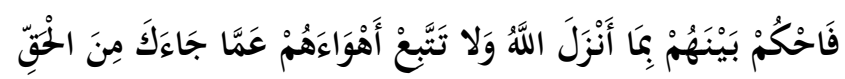

Artinya: "Maka putuskanlah perkara mereka menurut apa yang Allah turunkan dan janganlab kamu mengikuti bawa nafsu mereka dengan meninggalkan kebenaran yang telah datang kepadamu."(QS. AlMaidah: 48)

Oleh karena itu, hal ini menuntut seorang pemimpin untuk melaksanakan tugas-tugas berikut ini:

a. Menegakkan Keadilan Dan Memberantas Kezhaliman

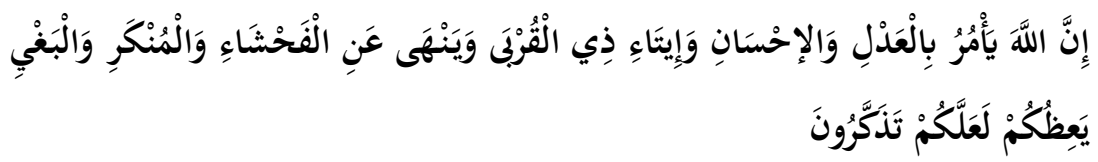

Artinya: "Sesunggubnya Allah menyuruh (kamu) berlaku adil dan berbuat kebajikan, memberi kepada kaum kerabat, dan Allah melarang dari perbuatan keji, kemungkaran dan permusuban. Dia memberi pengajaran kepadamu agar kamu dapat mengambil pelajaran." (QS. An-Nahl: 90)

b. Menjaga Persatuan Umat Islam Dan Mencegah Perpecahan

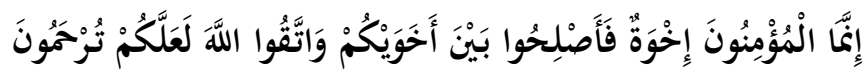

Artinya: "Sesunggubnya orang-orang mukmin adalah bersaudara karena itu damaikanlah antara kedua saudaramu dan bertakwalah kepada Allah supaya kamu mendapat rahmat," (QS. Al-Hujurat: 10)

Menjaga persatuan kaum Muslimin termasuk dasar tujuan tegaknya kepemimpinan. Banyak hal yang diperselisihkan dalam menjalankan ibadah. Sehingga dalam sebuah kaidah fiqhiyah para ulama menyebutkan 
Artinya: "Hukum atau ketetapan pemimpin mengbilangkan perbedaan." 7

1) Menjaga perbatasan wilayah dan menciptakan keamanan bagi setiap warga yang ada dalam kepemimpinannya. Imam Haramain Al-Juwaini berkata, "Perhatian pemimpin untuk menjaga perbatasan merupakan perkara yang cukup penting, yaitu dengan menjaga benteng perbatasan, menyimpan cadangan makanan yang cukup, menggali parit, serta menyediakan alat perlengkapan militer untuk pertahanan wilayah dan menyiapkan para pasukan di sepajang jalur perbatasan." 8

2) Mengelola kekayaan alam untuk kemaslahatan Islam dan kaum Muslimin

Diantara tujuan dari adanya kepemimpinan dalam Islam adalah mengelola kekayaan alam yang telah diciptakan oleh Allah. Sebagaimana firman-Nya:

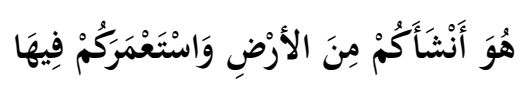

Artinya: "...Dia telah menciptakan kamu dari bumi (tanah) dan menjadikan kamu pemakmurnya...”(QS. Hud: 61)

Dengan demikian, di antara tujuan yang paling mendasar adanya konsep kepemimpinan dalam Islam adalah seorang pemimpin dipilih untuk melanjutkan tugas kenabian yang bertanggung jawab untuk menegakkan agama dan mengatur kemaslahatan dan keselamatan umat manusia dunia dan akhirat.

\section{G. Penutup}

Pemimpin adalah orang yang mendapat amanah serta memiliki sifat, sikap, dan gaya yang baik untuk mengurus atau mengatur orang lain. Kepemimpinan adalah kemampuan seseorang mempengaruhi dan memotivasi orang lain untuk melakukan sesuatu sesuai tujuan bersama. Pemimpin harus harus didasari imani, ta'abbudi, amal sholeh dan akhlaqul karimah dalam menjalankan kepemimpinannya untuk mencapai kesejahteraan dan keselamatan ummat dunia dan akhirat

\footnotetext{
7 Al-Qarafi, Al-Furuq, 2, h. 103

8 Al-Juwaini,Ghiyasul Umam, h. 156.
} 
Dalam Al-Quran dan as-Sunnah dikenal beberapa kata sebutan untuk kepemimpinan antara lain: Khalifah, Amiir (ulul amr), dan Imamah, wilayah, dan ri'ayah. Seorang pemimpin minimal harus memiliki empat aspek sebagaimana Rasulullah SAW mencontohkan, yaitu: Shiddiq, Amanah, Tabligh dan Fathanah. Shiddiq berarti jujur dalam perkataan dan perbuatan, amanah berarti dapat dipercaya dalam menjaga tanggung jawab, Tabligh berarti menyampaikan segala macam kebaikan kepada rakyatnya dan fathanah berarti cerdas dalam mengelola masyarakat. 


\section{Daftar Pustaka}

Abu 'Abdillah Muhammad ibn Isma'il al-Bukhari, al-Jami' al-Sabih alMusnad min Hadis Rasulillah Sallallahu 'alaibi wa Sallam wa Sunanibi wa Ayyamibi, Jil. III Kairo: al-Matkba'ah al-Salafiyyah, $1403 \mathrm{H}$.

Eaton, Gai. Islam dan takdir manusia. Yogyakarta: Suluh press. 2006.

Hakim, Abdul. Kepemimpinan Islami. Semarang: Unissula Press. 2007.

Imaad al-Din Abu al-Fida' Isma'il ibn Katsir al-Dimasyqi, Tafsir alQur'an al-Az̧him, Jil. XI Kairo: Muassasah Qurtubah, 2000.

John C. Maxwell, The 21 Indispensable Quality of Leader

Kartini Kartono, Pemimpin dan Kepemimpinan, Raja Gravindo Persada, Jakarta, 2004.

Rachmat Ramadhana al-Banjari, Prophetic Leadership Yogyakarta: DIVA Press, 2008.

Taimiyah, Ibnu. "Majnu Al-Fatwa" Dalam Dr. Syamsul Munir Amin, Ilmu Dakwah, Jakarta ; Amzah, 2009.

Yulistina, Tina. Kepemimpinan Model Nabi. Malang: Qalam Grup. 2007.

Yunus, Mahmud. Kamus Arab- Indonesia. Jakarta: Mahmud Yunus wadzuriyyah, 1998. 
Hafniati 